\title{
Reproductive processes in two oak (Quercus) contact zones with different levels of hybridization
}

\author{
JOSEPH H. WILLIAMS*†, WILLIAM J. BOECKLEN $\dagger+\&$ DANIEL J. HOWARD $\dagger$ \\ $\dagger$ Department of Biology, MSC 3AF, $\ddagger$ Department of Experimental Statistics, MSC 3CQ, PO Box 30001, New Mexico \\ State University, Las Cruces, NM 88003, USA
}

\begin{abstract}
Patterns of reproductive isolation between two sympatric species of oaks, Quercus gambelii and Q. grisea, that exhibit strong ecological differentiation were examined. A full diallel cross using four trees of each species (i.e. all possible pollinations among eight trees) was performed. This design was repeated at two sites that represent different outcomes of sympatry: (1) a xeric mountain ridge where many hybrids are established (HZ); and (2) a mesic valley bottom where virtually no hybrids are established (MOCYN). By measuring fruit survival at several developmental stages, both the timing and strength of reproductive barriers within and between sites, species, cross types, and pollen dosage levels were examined. In three of four cases, heterospecific fruit set was significantly reduced compared to conspecific fruit set. This reduction occurred after the time of fertilization, but before the onset of embryo growth. Increasing the dose of pollen from an average of 9-194 grains/stigma did not affect this result. Thus, early postfertilization processes play a strong role in species fidelity in these oaks. Quercus gambelii experienced a five-fold decrease in conspecific fruit set at $\mathrm{HZ}$ relative to MOCYN. In contrast, heterospecific fruit set of Q. gambelii was the same at both sites. Poor $Q$. gambelii pollen performance is implicated as playing the major role in this result. One $Q$. gambelii individual at $\mathrm{HZ}$ was highly fecund, and had higher heterospecific than conspecific fruit set; slight introgression in this tree was detected uisng RAPD markers. The Environmental Emasculation Hypothesis that posits that environmental stress can increase the probability of hybrid formation by reducing the competitive ability of male gametes of one species is proposed.
\end{abstract}

Keywords: environmental emasculation hypothesis, hybrid zone, pollen competition, pollen quality, RAPD markers, reproductive barriers.

\section{Introduction}

Oaks represent a classic example of a taxonomic group in which individual species maintain distinct morphological, genetic and ecological identities despite extensive hybridization and introgression within the group (Stebbins, 1950; Burger, 1975; Grant, 1981; Whittemore \& Schaal, 1991). Because oaks appear to have weak internal barriers to hybridization, it has long been argued that the degree to which hybrids appear is largely dependent on factors that control seedling establishment and survival (Muller, 1952; Stebbins et al., 1947; Rushton, 1993). Oaks, along with other wind-pollinated

*Correspondence and present address: Department of EPO Biology, University of Colorado, Boulder, CO 80309, USA. E-mail: joe. williams@colorado.edu species, are seen as bearing the 'cost' of hybridization, producing many hybrid offspring that are destined either to fail or to be restricted to narrow or ephemeral habitats (Grant, 1958; Stebbins et al., 1947; Hardin, 1975). As a result, oaks have been proposed as a model taxon for species concepts that rely on ecological criteria, rather than reproductive isolation, in delimiting species boundaries (Van Valen, 1976).

Ecological differentiation can act as a strong external barrier to gene flow. It can also influence internal reproductive barriers, although this possibility has generally been overlooked in the literature on oaks and on the formation and maintenance of hybrid zones (e.g. Anderson, 1948; Muller, 1952; Endler, 1977; Moore, 1977; Barton \& Hewitt, 1985). For example, it has often been noted that when the ranges of two species overlap broadly, hybrids occur more frequently at the 
geographical or ecological margins of one or both species (Grant, 1981; Stebbins, 1950). Typically, this result is attributed to the presence of nonparental habitat types in such areas, habitat types in which hybrid survival is enhanced (Anderson, 1948; Moore, 1977). However, another possible explanation for the increased abundance of hybrids in such habitats is the breakdown of mate recognition systems due to the stress associated with existence at the margin of a species range. Few studies have examined reproductive processes that contribute to the formation of natural plant hybrid zones (Arnold, 1997).

The Quercus gambelii Nutt. $\times$ Q. grisea Liebm. complex offers an opportunity to explore the role of internal reproductive barriers in modulating the occurrence and abundance of hybrids in zones of sympatry. These species exhibit geographical variation in the degree of hybridization (Tucker, 1961; R. Spellenberg, pers. comm.). In addition, there appears to be local variation; hybrid swarms are often found on xeric mountain slopes, but are rarely found in nearby mesic valleys. This study examines two such sites: (1) a site with a hybrid swarm containing a full range of intermediates; and (2) a contact zone with virtually no hybrid establishment. By comparing characteristics of individuals from sites with different levels of reproductive isolation, one may identify trait differences that account for the isolation. One may also gain insight into the processes contributing to the maintenance or loss of reproductive isolation. Specific traits studied at both sites were: (1) Comparative reproductive success of self, conspecific, and heterospecific experimental crosses; and (2) the relative timing of flower/fruit abortions from the time of fertilization to seed maturity. In addition, the effect of pollen dosage on flower/fruit survival was examined.

\section{Materials and methods}

\section{The species}

Quercus gambelii and $Q$. grisea are distantly related white oaks (subgenus Quercus; Nixon, 1993a). Quercus gambelii is most closely related to the mesic oaks of the Q. margaretta complex (Muller, 1952). Quercus grisea is most closely related to the xeric Mexican oaks (Nixon, 1993b). These two species are well separated in growth form, leaf anatomy, embryo structure, physiological tolerances and edaphic requirements. Quercus gambelii is commonly associated with the ponderosa pine belt of the south western U.S. mountains, whereas $Q$. grisea occurs at lower elevations as a codominant in the pinyon-juniper zone. The ranges of the two species overlap across a broad zone from northern Sonora/
Chihuahua, Mexico to southern Colorado (see Howard et al., 1997). The hybrids between $Q$. gambelii and $Q$. grisea plus five other southwestern USA oak species were formerly recognized as the species $Q$. undulata Torr. (Tucker, 1961).

\section{Study sites}

The two study sites are located in the northern San Mateo Mountains, near Magdalena, New Mexico. This mountain range rises from the Chihuahuan Desert to the south and the central New Mexican volcanic plateau to the north, and endemic oak populations are effectively isolated from other large populations of oaks. The nearest congener, $Q$. turbinella, occurs at lower elevations, approximately $80 \mathrm{~km}$ south of the study area. One can, therefore, study variation in the level of genetic isolation between $Q$. gambelii and $Q$. grisea free from the confounding influence of other oak species.

The first site (Hybrid Zone, or HZ) lies at an elevation of $2676 \mathrm{~m}$. This site contains both parental species and a full range of intermediates ('Mixed site' of Howard et al., 1997). The area is dry and along the slopes of a mountain ridge. Quercus grisea is near its upper elevation limit here, while $Q$. gambelii is at its lower elevation limit (with the exception of riparian areas). Codominants at the site include a diverse array of shrubs and trees such as Cercocarpus spp., Juniperus spp., Pinus edulis, P. flexilis, P. ponderosa, and Pseudotsuga menziesii. The soils are rocky and shallow, with little grass cover between trees.

The second site (Monica Canyon, or MOCYN) is approximately $6 \mathrm{~km}$ north of the first site, in a springfed valley at an elevation of $2346 \mathrm{~m}$. Here Q. gambelii is restricted to the deeper soils of the valley bottom, along with Pinus ponderosa, Populus angustifolia, Pseudotsuga menziesii, and Salix spp. Quercus grisea is largely restricted to the surrounding hillsides where it is a codominant with Pinus edulis and Juniperus spp. Morphological intermediates are conspicuously absent from this site.

At both sites, individuals of both species were common and relatively evenly distributed within their respective habitats. Contact zones were sharp transitional areas where both species often occurred within $1 \mathrm{~m}$ of each other. The contact zone at MOCYN is clearly delimited by a valley/hillside transition, whereas at $\mathrm{HZ}$ a more complex topography generally produced contact zones along north- and south-facing slopes. Individuals were relatively large and of single or few ramets at MOCYN and smaller and of multiple ramets at HZ. Both species flowered concurrently at the two sites (Williams \& Boecklen, unpubl. data). Thus, the two sites do not differ in the degree of sympatry. 


\section{Selection of trees}

In a study of phenology, we previously identified 10 reproductively mature trees of each species along parallel transects bordering a contact zone at each site (Williams \& Boecklen, unpubl. data). Species were identified according to habitat preference, growth form and leaf morphology. As slope and aspect can be important determinants of microhabitat segregation in oaks (Benson et al., 1967), an attempt was made to hold these constant within species. Four trees from each of these four transects were randomly selected for experimental pollinations. Conspecific individuals were $>40 \mathrm{~m}$ apart from each other, and there was no genetic evidence for clonal reproduction (Williams, unpubl. data). Voucher specimens of each of the 16 experimental trees were deposited in the New Mexico State University herbarium. Because hybridization clearly occurs at $\mathrm{HZ}$, the possibility existed that the experimental trees were not 'pure' representatives of $Q$. gambelii and $Q$. grisea. To assess this possibility, we characterized the trees via randomly amplified polymorphic DNA (RAPD) markers.

\section{RAPD analysis}

In a survey of 700 10-bp primers, Howard et al. (1997) identified six primers that generated eight banding regions consistent with eight independently inherited genetic loci. These loci yielded 14 informative character states, or markers (the presence or absence of a particular fragment), that distinguished three geographically isolated $Q$. gambelii populations $(n=41)$ from three geographically isolated $Q$. grisea populations $(n=20)$. The same markers also distinquished the two species locally at sites above and below the zone of overlap (within which the present study was conducted). These primers were then used to characterize trees from the zone of overlap and demonstrated that character index scores based on RAPD genotypes correlated well with a morphological classification of the trees (Howard et al., 1997).

The 16 chosen trees were characterised using the same six primers. A phenotype specific to $Q$. grisea was assigned a score of -1 . A phenotype specific to $Q$. gambelii was assigned a score of +1 . The character index score of an individual represented the sum of its scores over all six primers. Because the six primers generated six $Q$. grisea markers and eight $Q$. gambelii markers, the score of an individual could range from -6 to +8 . Two loci provided markers that were informative in one state but not in the alternative, thus a pure individual might not have the maximum score for that species. Mixed-species ancestry or introgression was indicated by the presence of markers typical of both species in a single individual.

\section{Experimental pollinations}

Before bud swelling occurred, 60 shoots of the previous year (= 'branch') on each experimental tree were selected from south-facing portions at mid canopy height, although on smaller trees some branches were also from the upper canopy. At each site a full diallel cross (Wright, 1976), consisting of all possible reciprocal crosses among the 8 experimental trees was performed. Each cross was performed at three pollen dosage levels. Thus, each tree received three doses $\times$ eight male donors $(=24$ treatments), each replicated twice. Each of the 48 treatments was randomly assigned to a branch. Unused branches were self-pollinated as, due to the design of a diallel cross, selfcrosses are poorly represented. Due to the unpredictability of flower production and slight losses due to wind and elk, several crosses were not fully replicated. This design allowed an assessment of male and female reproductive success as a function of site, species, cross type (self, conspecific or heterospecific), pollen dose and individual tree.

White oaks are wind-pollinated and monoecious. Male flowers, borne on dense inflorescences, or 'catkins', develop near the terminal end of the shoot of the previous year. Female flowers develop in the axils of the leaves from the shoot of current year. When bud swelling occurred in early May, male buds were stripped from branches, white paper bags (\#6) were sealed around each branch, and the female flower-bearing shoots allowed to grow into the bags. All branches were bagged well before female flowers became receptive. Female flower receptivity lasts up to two weeks, while pollen shedding can last up to one week (Wright, 1976). Within an individual tree pollen shedding began slightly before the onset of female flower receptivity. Bags were removed from branches after all chance of natural pollination was over.

As no control was possible over the number of female flowers produced in each pollination bag, it can be regarded as a measure of female reproductive effort. At the time of pollination, the number of receptive female flowers (those with swollen ovaries and reflexed stigmas) within each bag was recorded. Flowers that did not reach this stage could not be reliably counted, and were visually estimated on a 'per tree' basis. As a measure of male reproductive effort, male catkin production over the entire tree crown at the time of anthesis was visually estimated and ranked (methods modified from Sharp \& Chisman, 1961; Graves, 1980): $1=$ virtually no catkins; $2=$ only a few shoots with 
catkins; $3=\mathrm{a}$ few catkins on most shoots; $4=$ many catkins on almost all shoots.

Catkins approaching full elongation were collected from each tree and allowed to dry and dehisce in paper bags for up to $24 \mathrm{~h}$. For most trees, catkins were collected on two or more occasions to ensure freshness of pollen for later pollinations (i.e. pollen always $\leq 2$ days old). Pollen was stored in vials, and moisture content and temperature were controlled by placing the vials in a dessicator on ice. Pollen viability was not assessed, but experimental crosses using oak pollen, including these same two species, have demonstrated high pollen viablity for over two weeks (Cottam et al., 1982; Wright, 1976; Steinhoff, 1993). Pollinations were performed by removing a bag and pollinating all flowers with swollen ovaries and wet stigmatic surfaces. The flowers on each tree were pollinated after the peak of pollen shedding of that tree. This is the time period when stigmas are maximally receptive (Wright, 1976). Windy conditions were avoided during pollinations. No rain fell during the entire pollination period.

Each flower was pollinated with one of three dosage levels. A low dose was applied with a piece of fishing line (0.45 mm diameter), a medium dose was applied with a toothpick, and a high dose was applied with a plasticfilamented touch-up paintbrush. An attempt was made to place pollen on the same area of the stigmatic lobes in all pollinations; however, high doses were necessarily more extensive in coverage. All pollinations were performed by JHW. Pollen applications were practiced beforehand and the number of grains counted until a consistent dosage level was attained. Flowers were periodically checked to confirm application levels (mean (SE) number of pollen grains/stigma: low $=9.3(1.3)$, medium $=30.4(4.4)$, high $=194.2(21.8)$ ). These doses are within the range of natural pollen loads (Williams \& Boecklen, unpubl. data).

\section{Flower and fruit survival}

Flower or fruit abortion is episodic in oaks and occurs during several distinct developmental stages (Table 1): during floral development (pollination period), during ovule development and pollen tube growth (period 1), and during formation of the endosperm and early embryo (period 2; Feret et al., 1982; Sork et al., 1993). After embryo growth begins (period 3), abortion is negligible and is often associated with herbivore damage (Williamson, 1966). A final period of maturation ends when the acorn falls from the tree (period 4). Differentiation between prezygotic (period 1) and postzygotic (periods 2-4) phenomena were determined by monitoring the success of crosses from pollination to maturity. In order to best represent the abortion peaks occurring within each developmental period, the number of surviving flowers/fruits was counted one week after the end of each of these developmental periods were counted (sampling points (SP) 1-4; Table 1). Fruits were considered to be aborted if they had fallen, if they had brown stalks indicative of impending abscission, and/or if they displayed browning at the base of the style or apex of the cupule (Sharp \& Sprague, 1967). For statistical analyses, fruit survival at SP1, SP2 and SP3 was calculated as the number of nonaborted fruits remaining divided by the number of flowers pollinated. At SP4, survival (fruit set) was calculated as the number of nonabortive acorns that fell into protective screens, divided by the number of flowers pollinated. Non-abortive acorns were characterized by embryo swelling extending above the cupule rim.

\section{Statistical analysis}

The experimental pollinations followed a full diallel cross at each site. However, the standard analysis for

Table 1 Timeline of developmental periods during white oak reproductive cycle (from Turkel et al., 1955; Stairs, 1964; Sharp \& Sprague, 1967 Mogensen, 1975; not to scale). Ovule formation begins after pollination, with the embryo sac being ready for fertilization 4-5 weeks later. After fertilization, endosperm development occurs first, with cell division of the zygote beginning 1-2 weeks later, there is little visible growth of the fruit during period 2. Flower/fruit survival from experimental pollinations was monitored 6 weeks, 10 weeks and 14 weeks after pollination (SP1, SP2, SP3); and at the end of mature fruit fall (SP4)

\begin{tabular}{lllll}
\hline $\begin{array}{l}\text { Pollination } \\
10-14 \text { days }\end{array}$ & \multicolumn{1}{c}{$\begin{array}{c}\text { Period 1 } \\
4-5 \text { weeks }\end{array}$} & $\begin{array}{l}\text { Period 2 } \\
\text { 4 weeks }\end{array}$ & $\begin{array}{l}\text { Period 3 } \\
4 \text { weeks }\end{array}$ & $\begin{array}{c}\text { Period 4 } \\
4-8 \text { weeks }\end{array}$ \\
\hline $\begin{array}{l}\text { pollination and } \\
\text { pollen germination }\end{array}$ & $\begin{array}{l}\text { pollen tube growth, } \\
\text { ovule formation and } \\
\text { fertilization }\end{array}$ & $\begin{array}{l}\text { cell division of endosperm } \\
\text { followed by differentiation } \\
\text { of early embryo }\end{array}$ & $\begin{array}{l}\text { embryo (acorn) } \\
\text { enlargement }\end{array}$ & $\begin{array}{l}\text { acorn ripening } \\
\text { and drop }\end{array}$ \\
$\begin{array}{l}\text { late May to } \\
\text { early June }\end{array}$ & $\begin{array}{l}\text { June to early } \\
\text { July }\end{array}$ & $\begin{array}{l}\text { July to early } \\
\text { August }\end{array}$ & $\begin{array}{l}\text { August to early } \\
\text { September }\end{array}$ & $\begin{array}{l}\text { September to } \\
\text { October }\end{array}$ \\
\hline
\end{tabular}

(c) The Genetics Society of Great Britain, Heredity, 87, 680-690. 
this design (see Lynch \& Walsh, 1998) was not used because we were not interested in estimating traditional variance components, such as those for sires and dams. Instead, the main interest was in differences in patterns of reproductive success in two different ecological settings. Thus, a nested, mixed-model ANOVA was used with site, species, cross-type, and pollen dose as fixed effects; trees nested within site and species, and branches nested within trees (error term), as random effects. Hypothesis tests were based on maximum likelihood ratio tests, which approximate a chi-squared $\left(\chi^{2}\right)$ distribution (Dixon et al., 1990). Models were constructed to examine variation in female and male function separately. The response variable for female function was percent fruit survival/treatment at SP1 and at SP4. The components of female function were analysed separately. In addition, male function was examined using the response variable of percent fruit survival/treatment at SP4 according to pollen donor trees.

\section{Results}

\section{RAPD analysis}

Character index scores of $Q$. grisea from allopatric populations range from -6 to -2 with a mean of -5.4 (Howard et al., 1997). Scores of Q. gambelii from allopatric populations range from +5 to +8 with a mean of +7.1 . The character index scores of the 16 study trees are listed in Table 2. Most of the Q. gambelii and $Q$. grisea individuals had scores within the range found among allopatric representatives of the species. The exceptions were $Q$. gambelii tree \#2, that had a score of +4 and $Q$. grisea tree \#16, that had a score of 0 . Six of the eight $Q$. gambelii trees and all of the $Q$. grisea trees displayed at least one RAPD character (a marker or the lack of a marker) typical of the other species (Table 2).

\section{Reproductive effort}

Male reproductive effort, as measured by catkin production, was consistently high in Q. grisea (Table 3 ). $Q$. gambelii was more variable, with some trees at $\mathrm{HZ}$ producing virtually no catkins. These same trees were among the highest female flower producers (Table 3). At $\mathrm{HZ}$, the pattern of high pollen production by $Q$. grisea and low pollen production by $Q$. gambelii was also reflected in a larger sample of trees (Williams \& Boecklen, unpubl. data).

Many $Q$. grisea flowers were aborted prior to maturation, and as a result, $Q$. gambelii produced 1.86 times as many receptive flowers as $Q$. grisea (Table 3 ).

\section{Fruit survival and maturation}

Fruit survival at the end of period 1 (SP1) differed significantly between species (Table 4). Quercus gambelii

\begin{tabular}{|c|c|c|c|c|}
\hline Species and location & Tree & Score & $\begin{array}{l}\text { \# markers } \\
\text { conspecific }\end{array}$ & $\begin{array}{c}\text { \# markers } \\
\text { heterospecific }\end{array}$ \\
\hline \multicolumn{5}{|l|}{ Quercus gambelii } \\
\hline \multirow[t]{5}{*}{ Hybrid zone } & 1 & +6 & 7 & 1 \\
\hline & 2 & +4 & 6 & 2 \\
\hline & 3 & +6 & 7 & 1 \\
\hline & 4 & +6 & 7 & 1 \\
\hline & 9 & +6 & 7 & 1 \\
\hline \multirow[t]{3}{*}{ Monica Canyon } & 10 & +7 & 7 & 0 \\
\hline & 11 & +6 & 6 & 0 \\
\hline & 12 & +6 & 7 & 1 \\
\hline Mean & & +5.88 & & \\
\hline \multicolumn{5}{|l|}{ Quercus grisea } \\
\hline \multirow[t]{4}{*}{ Hybrid zone } & 5 & -2 & 4 & 2 \\
\hline & 6 & -2 & 4 & 2 \\
\hline & 7 & -2 & 4 & 2 \\
\hline & 8 & -2 & 4 & 2 \\
\hline \multirow[t]{4}{*}{ Monica Canyon } & 13 & -2 & 4 & 2 \\
\hline & 14 & -2 & 4 & 2 \\
\hline & 15 & -4 & 5 & 1 \\
\hline & 16 & 0 & 3 & 3 \\
\hline Mean & & -2.00 & & \\
\hline
\end{tabular}

Table 2 Character index scores based on RAPD markers in Quercus gambelii and $Q$. grisea. Scores can range from $-6(Q$. grisea $)$ to +8 (Q. gambelii) 
Table 3 Male and female reproductive effort in Quercus gambelii and $Q$. grisea . Abscission $=$ relative estimate of the amount of female flower abscission observed during hand pollinations (i.e. flowers that failed to complete development and could not be pollinated); flowers $=$ the total number of receptive flowers pollinated; $n=$ the total number of pollination bags included in the analysis; catkins $=$ estimated male inflorescence production ranked on a scale of $0-4$

\begin{tabular}{lrlrrc}
\hline Species and location & Tree & Abscission & Flowers & $n$ & Catkins \\
\hline $\begin{array}{l}\text { Quercus gambelii } \\
\text { Hybrid zone }\end{array}$ & 1 & None & 397 & 50 & 1 \\
& 2 & None & 604 & 45 & 2 \\
& 3 & Low & 504 & 49 & 0 \\
Monica Canyon & 4 & None & 149 & 46 & 0 \\
& 9 & High & 69 & 23 & 0 \\
& 10 & None & 150 & 39 & 4 \\
Total & 11 & None & 258 & 45 & 4 \\
Quercus grisea & 12 & None & 648 & 51 & 4 \\
Hybrid zone & & & 2779 & 348 & \\
& & & & & \\
& 5 & None & 269 & 52 & 4 \\
Monica Canyon & 6 & Moderate & 349 & 48 & 4 \\
& 7 & Moderate & 82 & 39 & 4 \\
& 8 & High & 105 & 37 & 4 \\
Total & 13 & None & 235 & 46 & 3 \\
& 14 & Moderate & 202 & 43 & 3 \\
& 15 & High & 75 & 38 & 4 \\
\end{tabular}

Table 4 Anova results (maximum likelihood method) measuring fertilization success in terms of female function (\% fruit survival at SP1) in Quercus gambelii and Q. grisea

\begin{tabular}{lcrr}
\hline Effect & d.f. & Chi-square & \multicolumn{1}{c}{$P$} \\
\hline Site & 1 & 0.054 & 0.815 \\
Species & 1 & 14.413 & $<0.001$ \\
Cross & 2 & 0.926 & 0.629 \\
Dose & 2 & 0.593 & 0.743 \\
Site $\times$ Cross & 2 & 0.661 & 0.719 \\
Site $\times$ Dose & 2 & 1.688 & 0.430 \\
Site $\times$ Species & 1 & 0.132 & 0.716 \\
Species $\times$ Cross & 2 & 14.588 & 0.001 \\
Species $\times$ Dose & 2 & 0.531 & 0.531 \\
Cross $\times$ Dose & 4 & 0.625 & 0.960 \\
Site $\times$ Species $\times$ Cross & 2 & 0.315 & 0.315 \\
Trees (Site, Species) & 1 & 72.811 & $<0.001$ \\
\hline
\end{tabular}

had lower overall fruit survival during this time period than did Q. grisea (Fig. 1). In both species, fruits resulting from conspecific and heterospecific fertilizations survived with equal frequency (Fig. 1). In contrast, self-crosses survived differently than nonself crosses. In $Q$. gambelii, fewer self than nonself crosses survived to SP1. In $Q$. grisea more self than nonself-crosses survived to SP2 (Fig. 1). The significance of this difference is confirmed by the high $\chi^{2}$ value of the species $\times$ cross interaction (Table 4).

The final factor to have a significant effect on fruit survival during period 1 was trees (Table 4). This finding indicates there was variation in fruit survival among individual trees. Site and dose did not influence fruit survival, nor were any other interactions significant (Table 4).

Fruit survival measured at SP2 was virtually identical to fruit survival at SP3 and SP4 (i.e. fruit set). Only $3.5 \%$ of all crosses aborted during the 3 months between SP2 and SP4. Therefore, rather than evaluating fruit survival at SP2, 3 and 4 separately, only the data from SP4 is reported, recognizing that these results occurred during period 2.

In contrast to SP1, species effects were nonsignificant at SP4 (Fig. 2; Table 5). Total fruit set was equivalent in both species (mean $( \pm \mathrm{SE}$ ) fruit set for $Q$. gambelii $=0.121(0.015)$, for $Q$. grisea $=0.127(0.018))$. The effect of dose, both as a main effect and in all interactions, was also nonsignificant (Table 5).

Cross type was significant both as a main effect and in all interactions other than dose (Fig. 2; Table 5). In general, conspecific outcrosses were more successful than self- and heterospecific crosses. However, the significant site $\times$ species $\times$ cross interaction highlights a dramatic reduction in conspecific outcrossing success for Q. gambelii at HZ. Quercus gambelii conspecific fruit set dropped almost five-fold from MOCYN to $\mathrm{HZ}$ $\left(\chi^{2}=5.42, \quad P=0.02, \quad\right.$ d.f. $=1 ; \quad$ Fig. 2$)$. In contrast, $Q$. gambelii heterospecific fruit set did not differ between MOCYN and $\mathrm{HZ}\left(\chi^{2}=1.04, P=0.31\right.$, d.f. $=1$; Fig. 2$)$. Thus, when $Q$. gambelii pollen was applied to Q. gambelii stigmas fruit set was poor, whereas when $Q$. grisea pollen was applied, fruit set was relatively high. This pattern of variation suggests that $Q$. gambelii 

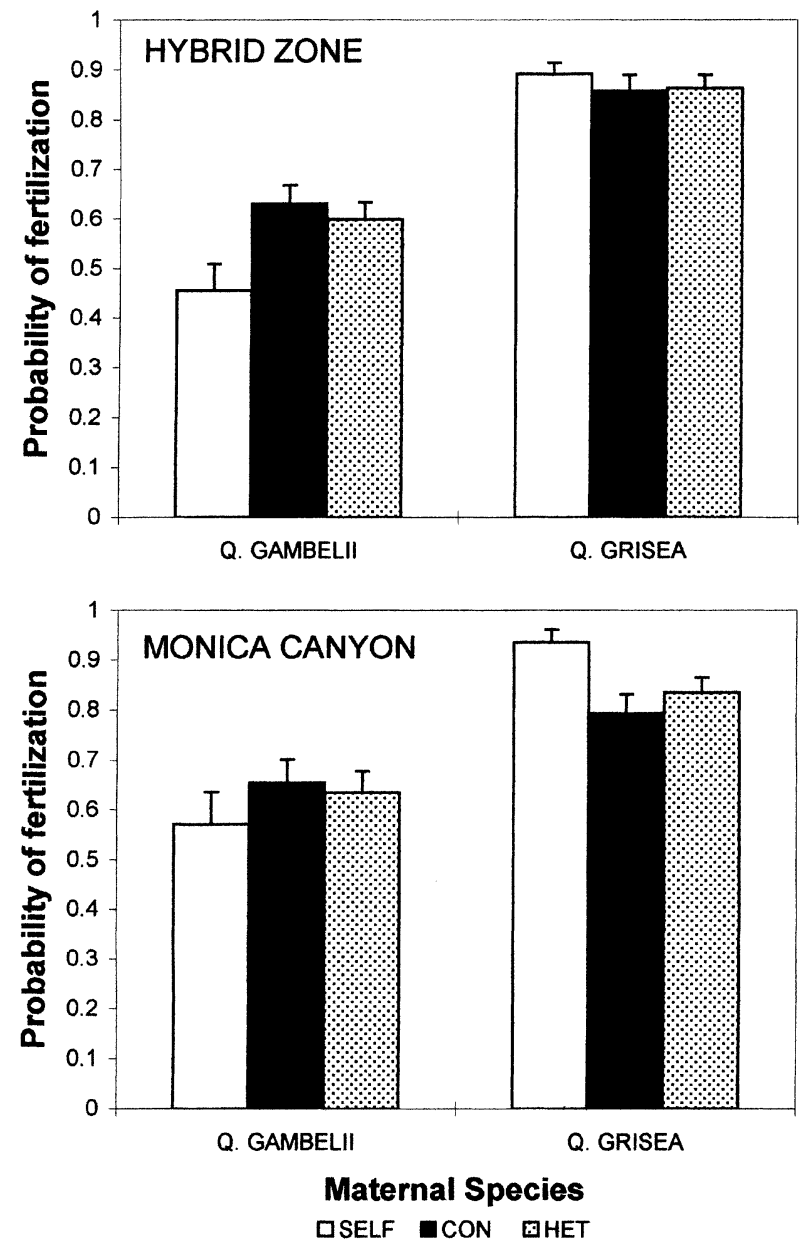

Fig. 1 Percent fruit survival 6 weeks after pollination (SP1). $\mathrm{CON}=$ conspecific; $\mathrm{HET}=$ heterospecific. Error bar $=1 \mathrm{~S} . \mathrm{E}$.

females at $\mathrm{HZ}$ were fertile and that the reduction in their conspecific outcrossing success was largely attributable to poor $Q$. gambelii pollen performance.

The reproductive success (RS) of $Q$. gambelii males at $\mathrm{HZ}$ was lower than the RS of all other groups of males. The significance of this difference is confirmed by a male function, site $\times$ species interaction effect (Table 6). At $\mathrm{HZ}, Q$. gambelii pollen performed poorly regardless of the species to which it was applied.

\section{Discussion}

\section{Variation in reproductive success in Quercus gambelii}

Quercus grisea had equivalent reproductive success at both sites for each cross type. In contrast, the conspecific cross type of $Q$. gambelii was significantly less successful at $\mathrm{HZ}$ than MOCYN. One possible explanation for this outcome is stress. Quercus gambelii
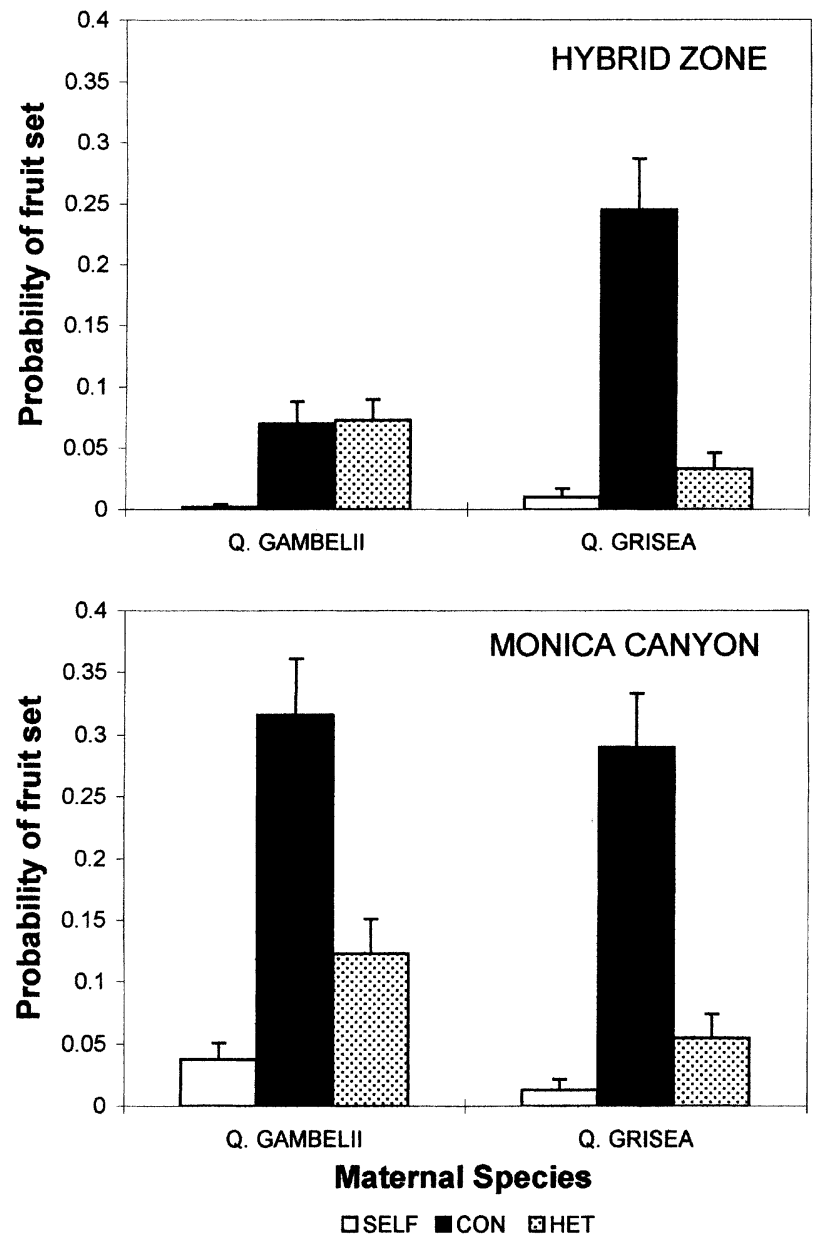

Fig. 2 Percent fruits matured (SP4). CON = conspecific; $\mathrm{HET}=$ heterospecific. Error bar $=1$ S.E.

Table 5 Anova results (maximum likelihood method) measuring fruit set in terms of female function (\% fruits matured at SP4) in Quercus gambelii and Q. grisea

\begin{tabular}{lcrr}
\hline Effect & d.f. & Chi-square & \multicolumn{1}{c}{$P$} \\
\hline Site & 1 & 2.926 & 0.087 \\
Species & 1 & 0.022 & 0.882 \\
Cross & 2 & 119.857 & $<0.001$ \\
Dose & 2 & 2.612 & 0.271 \\
Site $\times$ Cross & 2 & 11.188 & 0.004 \\
Site $\times$ Dose & 2 & 1.315 & 0.518 \\
Site $\times$ Species & 1 & 1.134 & 0.287 \\
Species $\times$ Cross & 2 & 15.979 & $<0.001$ \\
Species $\times$ Dose & 2 & 1.465 & 0.481 \\
Cross $\times$ Dose & 4 & 1.657 & 0.798 \\
Site $\times$ Species $\times$ Cross & 2 & 7.932 & 0.019 \\
Trees (Site, Species) & 1 & 52.798 & $<0.001$ \\
\hline
\end{tabular}


Table 6 Anova results (maximum likelihood method) measuring fruit set in terms of male function (\% fruits matured at SP4) in Quercus gambelii and Q. grisea

\begin{tabular}{lcrc}
\hline Effect & d.f. & Chi-square & $P$ \\
\hline Site & 1 & 8.279 & 0.004 \\
Species & 1 & 0.067 & 0.796 \\
Cross & 2 & 98.716 & $<0.001$ \\
Dose & 2 & 2.913 & 0.233 \\
Site $\times$ Cross & 2 & 10.465 & 0.005 \\
Site $\times$ Dose & 2 & 1.145 & 0.564 \\
Site $\times$ Species & 1 & 4.310 & 0.038 \\
Species $\times$ Cross & 2 & 8.835 & 0.012 \\
Species $\times$ Dose & 2 & 1.395 & 0.498 \\
Cross $\times$ Dose & 4 & 1.233 & 0.873 \\
Site $\times$ Species $\times$ Cross & 2 & 5.349 & 0.069 \\
Trees $($ Site, Species) & 1 & 3.531 & 0.060 \\
\hline
\end{tabular}

is a northerly distributed, mesic habitat species, that may be under considerable stress at the $\mathrm{HZ}$ site. At this site, representatives of $Q$. gambelii occur on dry, inorganic hillside soils. In contrast, at the MOCYN site, $Q$. gambelii occurs on a valley floor that has richer, wetter soils. It is likely that $Q$. grisea is under less stress at $\mathrm{HZ}$ than $Q$. gambelii, because at both sites it occurs on dry hillsides, a fairly typical habitat for the species.

Environmental stress can affect sexual reproduction through a reduction of male or female function, or both (Freeman et al., 1981; Bertin, 1988; Young \& Stanton, 1990; Stephenson et al., 1993; Delph et al., 1997; Saini, 1997). For example, Aizen \& Raffaele (1998) report significant reduction in pollen quality in Alstroemeria aurea following artificial defoliation, while Lau \& Stephenson (1993, 1994) document reduced pollen quality and siring success in Cucurbita pepo grown in either nitrogen or phosphorus poor soils. The results reported here suggest that a reduction in male function is responsible for the poor reproductive success of conspecific pollinations of $\mathrm{HZ} Q$. gambelii. Female function is less implicated as a factor in this result because heterospecific fruit set of $\mathrm{HZ} Q$. gambelii was not significantly reduced relative to that of MOCYN Q. gambelii. Moreover, male RS was reduced in $\mathrm{HZ}$ Q. gambelii regardless of cross type. Another indication of poor male function was the very low pollen production of $\mathrm{HZ} Q$. gambelii. Low pollen production can be associated with low pollen vigour (Schlichting, 1986; Schoper et al., 1986; but see Cruzan, 1990). Female flower production, conversely, was not low in Q. gambelii at $\mathrm{HZ}$ (Table 3). Thus, factors associated with male performance appear to play a stronger role than those associated with female performance in causing low conspecific outcrossing success of $\mathrm{HZ}$ Q. gambelii.

In light of this conclusion, it might be argued that the Q. gambelii trees at $\mathrm{HZ}$ are introgressed, which caused a reduction in pollen viability or vigour. This argument is not supported by the RAPD analysis. The RAPD profiles of the four $Q$. gambelii trees at $\mathrm{HZ}$ were similar to the profiles of the trees at MOCYN (Table 2). Moreover, Q. gambelii tree \#2 with the lowest character index score at $\mathrm{HZ}$, hence, the most highly introgressed tree, produced considerably more pollen than the other trees at HZ. In addition, the pollen of this tree had nonzero siring success on all other females, conspecific or heterospecific. Finally, the lack of a pollen dose effect suggests that reduced male function was not due to a reduction in the number of viable pollen grains produced, which might be expected if introgression had led to disturbed meiosis. Thus, introgression does not appear to explain the reduction in male function observed among $Q$. gambelii at $\mathrm{HZ}$.

\section{Environmental Emasculation Hypothesis}

The results reported here are consistent with the hypothesis that the formation of hybrid zones in the Quercus gambelii $\times Q$. grisea species complex is a consequence of diminished male function in $Q$. gambelii owing to environmental stress. One effect of decreased male function in $Q$. gambelii would be an increase in hybrid fruit set relative to conspecific fruit set. Thus, one explanation for the increased frequency of hybrids at the $\mathrm{HZ}$ site is poor pollen quality in $Q$. gambelii. Poor pollen quality also reduces pollen competitive ability, and pollen competition can be an important arbiter of species boundaries in other wind-pollinated tree species (Williams et al., 1999). An obvious, but untested, prediction of this hypothesis is that most of the hybrids at this site should harbour $Q$. gambelii mitochondrial and chloroplast DNA.

Asymmetric patterns of introgression appear to be common in both European and American oaks (Whittemore \& Schaal, 1991; Ferris et al., 1993; Bacilieri et al., 1996; Dumolin-Lapègue et al., 1997; Howard et al., 1997). There is also evidence of asymmetric crosscompatibility between oak species (Aas, 1991; Steinhoff, 1993). At least one study has sought to explain such patterns through a combination of ecological, demographic and reproductive factors, including male function (Petit et al., 1997). This study offers a new explanation for both variation in hybrid zone formation as well as for why such zones often display asymmetric patterns of hybridization, although these data cannot be viewed as a test of the environmental emasculation hypothesis. A test of the hypothesis would require zones 
of sympatry (both with and without significant hybridization) to be the experimental units, and the present experimental design had no replication at the level of zones of sympatry.

Some models of hybrid zone dynamics assume that hybrids are inherently less fit than their parents (Endler, 1977; Barton, 1979; Barton \& Hewitt, 1985), while other models assume that hybrids have reduced fitness in parental environments but increased fitness in novel or intermediate environments (Anderson, 1948; Moore, 1977). Arnold \& Hodges (1995) have argued that reduced hybrid fitness measured in many studies is often an average across a heterogeneous array of genotypic classes. The discovery that the most successful producer of pollen and fruits among the $Q$. gambelii at the HZ site (tree \#2) appeared to be an advanced backcross, represents further evidence that some hybrids are not necessarily less fit than their parents, particularly in marginal habitats.

\section{Flower and fruit abortion}

Many long-lived perennials, including oaks, produce far more flowers than mature fruits (Stephenson, 1981). Three periods of heavy flower/fruit abortion were recorded. Both species had substantial flower abortion prior to fertilization ( $Q$. grisea before pollination, Q. gambelii after pollination). Importantly, these abortions were random with respect to cross type, and suggest an early maternal adjustment to resource availability (Lloyd, 1980).

Mate discrimination in white oaks appears to be a consequence of postzygotic processes. Self-pollinated flowers aborted at the same rate as conspecific and heterospecific flowers before fertilization (period 1), but were nearly completely eliminated after fertilization (during period 2). In addition, the low heterospecific RS seen in both species also occurred during period 2 , as well as the dramatic reduction in $Q$. gambelii conspecific RS at HZ (compare Figs 1 and 2). Almost no abortions occurred during acorn growth and maturation (periods 3 and 4). This pattern suggests mate recognition occurs via postzygotic mechanisms, such as late-acting incompatibility and inbreeding or outbreeding depression, but not by prezygotic self or hetero specific incompatibility.

The abortion peak late in period 2 corresponds to the period when the early embryo first undergoes differentiation. Wiens et al. (1987) suggest that a heavy clustering of developmental lethals at this time is the major cause of conspecific embryo abortion in outcrossing species. Poor pollen quality may also lead to increased embryo abortion. For example, slower pollen tube growth may result in delayed fertilization, leading to developmental selection amongst embryos (Buchholz,
1922). It has been shown in other flowering plants, such as Phaseolus spp., that seeds with late-forming endosperm and embryos have a higher likelihood of abortion (Rabakoarihanta et al., 1979; Nakamura, 1986).

An alternative interpretation of the high abortion rate in period 2 is that these abortions represent unfertilized flowers which aborted late. This interpretation seems unlikely, for several reasons. First, ample time was allowed for crosses that could not fertilize eggs to express signs of abortion. In fact, during period 1, discrimination between self and nonself was expressed through differential flower abortion (Fig. 1). Second, almost all abortions recorded at SP1 were flowers that had already fallen, rather than flowers that were turning brown (J. H. Williams, pers. obs.). This indicates that SP1 occurred well after an earlier abortion peak. In contrast, at SP2 many aborted fruits were still on the tree (i.e. fruits turning brown and/or initiating an abscission layer). This indicates that the second abortion peak occurred late in period 2. Thus, if the abortions which occurred during period 2 were due to lack of fertilization, the delay of any sign of impending abortion was approximately 4-6 weeks long. It appears that both the reduced heterospecific RS and the reduced conspecific RS of Q. gambelii at $\mathrm{HZ}$ were due to an increase in embryo abortion rather than to a decrease in the ability of pollen tubes to fertilize ovules.

\section{Pollen dosage experiment}

Heterospecific pollen swamping of isolated plants has been implicated in the production of hybrids in nature (e.g. Arnold et al., 1993; Tucker, 1963; Williams et al., 1999). If variation exists for pollen tube growth rate or vigour, then increasing the amount of heterospecific pollen on a stigma might be expected to increase the probability of fertilization. In fact, neither conspecific or heterospecific fertilization increased when pollen loads were increased from approximately 9-194 pollen grains. This is further evidence for a lack of strong prefertilization barriers in these species, at least when heterospecific pollen occurs alone on a stigma. Whether conspecific pollen outcompetes heterospecific pollen for fertilizations when both types of pollen occur on a stigma awaits further study.

\section{Conclusions}

In oaks and many other groups of species, the level of reproductive isolation between closely related species varies geographically. By comparing characteristics of individuals from areas with different levels of reproductive isolation it becomes possible to pinpoint factors that mediate reproductive isolation. The results of this study 
indicate that marginal habitats can increase the probability of hybrid offspring formation by altering the quantity and quality of male gametes (environmental emasculation) of one parental species.

\section{Acknowledgements}

We thank R. Spellenberg, L. Huenneke, M. O'Connell, M. Arnold, S. Emms, J. Burke, S. Carney, M. Hare, D. Campbell, and V. Sork for helpful suggestions on an earlier draft of this manuscript, and M. Folsom for assistance at an early stage of this project. We acknowledge the cooperation of the Cibola National Forest personnel in the Magdalena Ranger District. This study was supported by a Grant-in-Aid of Research from Sigma Xi, a NMSU Summer Research Award for Excellence in Graduate Studies, a NMSU Biology Graduate Research Assistance Grant, and a New Mexico Commission on Higher Education Graduate Student Research Project Award to J. H. Williams; and by National Science Foundation grants DEB-9209109 and DEB-9632154 to WJB and DJH.

\section{References}

AAs, G. 1991. Kreuzungsversuche mit Stiel-und Traubeneichen (Quercus robur L. \& Quercus petraea (Matt.) Liebl.). Allg. Forst-Jagdz., 162, 141-145.

AIZEN, M. A. AND RAFFAELE, E. 1998. Flowering-shoot defoliation affects pollen grain size and postpollination pollen performance in Alstroemeria aurea. Ecology, 79, 2133-2142. ANDERSON, E. 1948. Hybridization of the habitat. Evolution, 2, $1-9$.

ARNOLD, M. L. 1997. Natural Hybridization and Evolution. Oxford University Press, Oxford.

ARNOLD, M. L., HAMRICK, J. H. AND BENNETT, B. D. 1993. Interspecific pollen competition and reproductive isolation in Iris. J. Hered., 84, 13-16.

ARNOLD, M. L. AND HODGES, S. A. 1995. Are natural hybrids fit or unfit relative to their parents? Trends Ecol. Evol., 10, 67-70.

BACILIERI, R. A., DUCOUSSO, A., PETIT, R. J., BACILIERI, R. AND KREMER, A. 1996. Mating system and asymmetric hybridization in a mixed stand of European oaks. Evolution, 50, 900-908.

BARTON, N. H. 1979. The dynamics of hybrid zones. Heredity, 43, 341-359.

BARTON, N. H. AND HEwitT, G. M. 1985. Analysis of hybrid zones. Ann. Rev. Ecol. Syst., 16, 113-148.

BENSON, L., PHILLIPS, E. A. AND WILDER, P. A. 1967. Evolutionary sorting of characters in a hybrid swarm. 1. Direction of slope. Am. J. Bot., 54, 1017-1026.

Bertin, R. I. 1988. Paternity in plants. In: Lovett Doust, J. and Lovett Doust, L. (eds) Plant reproductive ecology, pp. 30-59. Oxford University Press, Oxford.

BuchHolz, J. т. 1922. Developmental selection in vascular plants. Bot. Gaz., 73, 249-286.
BURGer, w. C. 1975. The species concept in Quercus. Taxon, 24, 45-50.

COTTAM, w. P., TUCKer, J. M. AND SANTAMOUR, F. S. 1982. Oak Hybridization at the University of Utah. State Arboretum of Utah, Salt Lake City, UT.

CRUZAN, M. B. 1990. Variation in pollen size, fertilization ability, and postfertilization siring ability in Erythronium grandiflorum. Evolution, 44, 843-856.

DELPH, L. F., JOHANNSSON, M. H. AND STEPHENSON, A. G. 1997. How environmental factors affect pollen performance: ecological and evolutionary perspectives. Ecology, 78, 1632-1639.

DIXON, W. J., BROWN, M. B., ENGELMAN, L. AND JENNRICH, R. I. 1990. BMDP Statistical Software Manual. University of California Press, Berkeley.

DUMOLIN-lAPÈgue, S., DEMESURE, B. AND PETIT, R. J. 1997. Phylogeographic structure of white oaks throughout the European continent. Genetics, 146, 1475-1478.

ENDLER, J. A. 1977. Geographic Variation, Speciation, and Clines. Princeton University Press, Princeton.

FERET, P. P., KREH, R. E., MERKLE, S. A. AND ODERWALD, R. G. 1982. Flower abundance, premature acorn abscission, and acorn production in Quercus alba. Bot. Gaz., 143, 216-218.

FERris, C., OLIVER, R. P., DAVY, A. J. AND HEWITT, G. M. 1993. Native oak chloroplasts reveal an ancient divide across Europe. Mol. Ecol., 2, 337-344.

FREEMAN, D. C., MCARTHUR, E. D., HARPER, K. T. AND BLAUER, A. C. 1981. Influence of environment on the floral sex ratio of monoecious plants. Evolution, 35, 194-197.

GRANT, v. 1958. The regulation of recombination in plants. Cold Springs Harbor Symp., 23, 337-363.

GRANT, v. 1981. Plant Speciation. Columbia University Press, New York.

GRAVES, w. C. 1980. Annual Oak Mast Yields from Visual Estimates. In: Proceedings of the symposium on the ecology, management, and utilization of California oaks, pp. 270-274. Pacific Southwest Forest and Range Experimental Station, Forest Service, USDA, Berkeley.

HARDIN, J. W. 1975. Hybridization and introgression in Quercus alba. J. Arn. Arb., 56, 336-363.

HOWARD, D. J., PRESZLER, R. W., WILLIAMS, J. H., FENCHEL, S. AND BOECKLEN, W. J. 1997. How discrete are oak species? Insights from a hybrid zone between Quercus grisea and Quercus gambelii. Evolution, 51, 747-755.

LAU, T. C. AND STEPHENSON, A. G. 1993. Effects of soil nitrogen on pollen production, pollen grain size, and pollen performance in Cucurbita pepo (Cucurbitaceae). Am. J. Bot., 80, 763-768.

LAU, T. C. AND STEPHENSON, A. G. 1994. Effects of soil phosphorous on pollen production, pollen size, pollen phosphorous content, and the ability to sire seeds in Cucurbita pepo (Cucurbitaceae). Sex. Plant Reprod., 7, 215-220.

LLOYD, D. G. 1980. Sexual strategies in plants. 1. A hypothesis of serial adjustment of maternal investment during one reproductive session. New Phyt., 86, 69-79.

LYNCH, M. AND WALSh, B. 1998. Genetics and Analysis of Quantitative Traits. Sinauer, Sunderland, MA. 
MOGENSEN, H. L. 1975. Ovule abortion in Quercus (Fagaceae). Am. J. Bot., 61, 160-165.

MOORE, w. S. 1977. An evaluation of narrow hybrid zones in vertebrates. Q. Rev. Biol., 52, 263-277.

MULlER, C. H. 1952. Ecological control of hybridization in Quercus: a factor in the mechanism of evolution. Evolution, 6, 147-161.

NAKAMURA, R. R. 1986. Maternal investment and fruit abortion in Phaseolus vulgaris. Am. J. Bot., 73, 1049-1057.

NIXON, K. C. 1993a. Infrageneric classification of Quercus (Fagaceae) and typification of sectional names. Ann. Sci. For. (Paris), 50 (Suppl. 1), 25-34.

NIXON, K. C. 1993b. The genus Quercus in Mexico. In: Ramamoorthy, T. P., Bye, R., Lot, A. and Fa, J. (eds) Biological Diversity of Mexico, pp. 447-458. Oxford University Press, Oxford.

PETIT, R. J., PINEAU, E., DEMESURE, B., BACILIERI, R., DUCOUSSO, A. AND KREMER, A. 1997. Chloroplast DNA footprints of postglacial recolonization by oaks. Proc. Natl. Acad. Sci. U.S.A., 94, 9996-10001.

RABAKOARIHANTA, A., MOK, W. S. AND MOK, M. C. 1979. Fertilization and early embryo development in reciprocal interspecific crosses of Phaseolus. Theor. Appl. Gen., 54, 55-59.

RUSHTON, B. S. 1993. Natural hybridization within the genus Quercus L. Ann. Sci. For. (Paris), 50 (Suppl. 1), 73-90.

SAINI, H. S. 1997. Effects water stress on male gametophyte development in plants. Sex. Plant Reprod., 10, 67-73.

SCHLICHTING, C. D. 1986. Environmental stress reduces pollen quality in Phlox: compounding the fitness deficit. In: Mulcahy, D. L., Mulcahy, G. B. and Ottaviano, E. (eds) Biotechnology and Ecology of Pollen, pp. 483-488. Springer, New York.

SCHOPER, J. B., LAMBERT, R. J. AND VASILAS, B. L. 1986. Maize pollen viability and ear receptivity under water and high temperature stress. Crop Sci., 26, 1029-1033.

SHARP, W. M. AND CHISMAN, H. H. 1961. Flowering and fruiting in the white oaks. 1. Staminate flowering through pollen dispersal. Ecology, 42, 365-372.

SHARP, w. M. AND SPRAGUE, v. G. 1967. Flowering and fruiting in the white oaks. Pistillate flowering, acorn development, weather, and yields. Ecology, 48, 243-251.

SORK, V. L., BRAMBLE, J. AND SEXTON, O. 1993. Ecology of mastfruiting in three species of North American deciduous oaks. Ecology, 74, 528-541.
STAIRS, G. R. 1964. Microsporogenesis and embryogenesis in Quercus. Bot. Gaz., 125, 115-121.

STEBbins, G. L. 1950. Variation and Evolution in Plants. Columbia University Press, New York.

StebBins, G. L., MATZKe, E. B. AND EPLING, C. 1947. Hybridization in a population of Quercus marilandica and Quercus ilicifolia. Evolution, 1, 79-88.

STEINHOFF, S. 1993. Results of species hybridization with Quercus robur L. \& Quercus petraea (Matt.) Liebl. Ann. Sci. For. (Paris), 50 (Suppl. 1), 137-143.

STEPHENSON, A. G. 1981. Flower and fruit abortion: proximate causes and ultimate functions. Ann. Rev. Ecol. Syst., 12, 253-279.

STEPHENSON, A. G., LAU, T., QUESADA, M. AND WINSOR, J. A. 1993. Factors that affect pollen performance. In: Wyatt, R. (ed.) Ecology and Evolution of Plant Reproduction, pp. 119-136. Chapman \& Hall, New York.

TUCKER, J. M. 1961. Studies in the Quercus undulata complex. I. A preliminary statement. Am. J. Bot., 48, 202-208.

TUCKER, J. M. 1963. Studies in the Quercus undulata complex 3. The contribution of Quercus arizonica. Am. J. Bot., 50, 699-708.

TURKEL, H. S., REBUCK, A. L. AND GROVE, A. R. JR. 1955. Floral morphology of white oak. Penn. State University Of. Bull., 593, $1-14$

VAN VALEN, L. 1976. Ecological species, multispecies, and oaks. Taxon, 2/3, 233-239.

WhitTEMORE, A. T. AND SCHAAL, B. A. 1991. Interspecific gene flow in sympatric oaks. Proc. Nat. Acad. Sci. U.S.A., 88, 2540-2544.

WIENS, D., CALVIN, C. L., WILSON, C. A., DAVERN, C. I., FRANK, D. AND SEAVEY, S. R. 1987. Reproductive success, spontaneous embryo abortion, and genetic load in flowering plants. Oecologia, 71, 501-507.

WILLIAMS, J. H. JR, FRIEDMAN, W. E. AND ARNOLD, M. L. 1999. Developmental selection within the angiosperm style: Using gamete DNA to visualize interspecific pollen competition. Proc. Natl. Acad. Sci. U.S.A., 96, 9201-9206.

WILliamson, M. J. 1966. Premature abscissions in white oak acorn crops. For. Sci., 12, 19-21.

WRIGHT, J. W. 1976. Introduction to Forest Genetics. Academic Press, New York.

YOUNG, H. J. AND STANTON, M. L. 1990. Influence of environmental quality on pollen competitive ability in wild radish. Science, 248, 1631-1633. 